The Geneva Papers on Risk and Insurance, 17 (No. 63, April 1992), 267-274

\title{
Worldwide Insurance - A Better Solidarity
}

\author{
by Ruy de Carvalho*
}

\section{Introduction}

In the last two decades, services have emerged as one of the key factors of economic development worldwide. Insurance and risk management activities have clearly contributed to this trend by increasing steadily, year by year, their importance in most of the world economies at a rate superior to the rate of GNP.

One consequence of this situation is that in one way or another, risk and insurance management problems have found their place in most international institutions and organizations.

The experience of the European Communities has been of course an impressive one. To those international specialized organizations like the CEA (Comité Européen des Assurances) and governmental organizations which have since a long time dealt with insurance such as the OECD and the UNCTAD, we have seen entering this new field other prestigious international institutions such as the GATT and the World Bank (through MIGA). It is therefore quite appropriate for the Geneva Papers to devote this issue to the analysis of insurance developments at this level of the organized world solidarity. ${ }^{1}$

Insurance is a sector that provides an increasingly wide range of services in significant areas of risks.

The risk transfer, which is one of the benefits of insurance services, is essential to all countries, including the developing countries, and this calls for the international spreading of these risks, namely in the case where they are very large and sophisticated risks.

This kind of international solidarity, if it is to be effective needs a liberalised framework. Otherwise the domestic insurance markets, especially in the smaller and weaker markets, may be scriously affected.

If the coverage of certain risks is not facilitated by an international liberalised trade of insurance, the alternative has to be found exclusively through reinsurance which involves less local participation and may affect, in a stronger way, the national balances of payments.

\footnotetext{
* President, The Portuguese Insurers Association and Mcmber of the Board of the Geneva Association. This paper has been adapted from the version presented at the Second Meeting of ASEC (Applied Service Economis Centre) in Geneva, May 1991.

1 The issue of insurance at GATT has been already dealt with extensively in the Geneva Papers No. 61, October 1991 .
} 
The other possibility is to develop national capacity which implies again an international support.

This second alternative gives to those markets much of the benefits that insurance can provide.

Increase in local investment and personal savings, and stabilisation, development and competitiveness of the different sectors and national economy as a whole are among those benefits.

An important point is to evaluate what the natural evolution of those insurance markets would be in the absence of a multilateral agreement in trade in services.

We have seen that insurance is more and better developed on liberal markets and some recent experiences within EEC have confirmed this.

In fact, less developed markets need free competition to progress and international competition may provide innovation in products, improve financial capacity, promote better underwriting skills and consequently more accurate pricing.

If we accept that an international liberalised framework is the adequate solution, it might be useful to think in alternative terms of a multilateral negotiation or a bilateral or restricted multilateral negotiation.

In the last decades some regional blocs have emerged in the international scene, such as EFTA and EEC, and more recently the North America Free Trade Area (NAFTA), if the liberalisation movement between USA and Mexico succeed. If these original blocs tend to proliferate and become wider, a negotiation between them has to happen in the future or, alternatively, there will be stronger competition between more powerful and obviously less flexible partners.

The basic question is that bilateral or restricted multilateral negotiations depend very much on the bargaining power of the parties envolved and most of the time this bargaining power is stronger as the negotiation circle is reduced.

It is natural that the different parties engaged in a negotiation want to concentrate their attention where they can better exert their bargaining power.

The new free trade area formed by USA and Canada and the negotiations between USA and Mexico could be explained by this fact and may also be looked as a reaction to the successful EEC progress in abolishing barriers to trade, both in goods and services.

Because the concentration of capacity and skills in regional organisations gives them better negotiation positions, an enlarged multilateral approach seems to be more interesting for developing countries. At the same time the asymmetries between countries or between regional blocs make international trade more difficult and its liberalisation, even if it occurs gradually, is one of the best ways to reduce or even climinate such asymmetries.

Another key point is that sometimes the driving force that generates the agreements is the practical action of the market leaders. In fact, when business opportunities arise the real entrepreneurs always find a way to overcome legal constraints and trade barriers.

This is why private initiatives sometimes precede the adapting of national laws and the conclusion of international agreements, which finally occur to legalise the practical achievements. 
This happens more frequently with investments or joint ventures along the border line of countries with different levels of economic development.

Quite often these non-official liberalising movements may cause harmonisation of economic conditions of production and distribution and, in the end, harmonisation at price levels.

Because of their nature, services may "circulate" more easily, and then they can play an even more important role in this "levelling of prices".

Insurance is one of the financial services that can be a good example of this, with the exception of some "after-sales" services. Fronting and reinsurance are two possibilities for providing cross-border services without international agreement support, except for money transfers.

\section{The 1993 Internal Market}

In 1993 the Internal Market in Europe will be based on the abolition of intra-Community frontiers, liberalization of financial services and the opening of public markets.

Since most exchanges of goods and services of the European Community take place between its member States, the 1993 Internal Market will above all call for reorganization of the productive framework and technological progress of the Community space, and this will make it possible to be more optimistic in facing competition from other economic powers, namely the USA, Japan and the New Industrial Countries, and to have a different opening to the Eastern Countries and Developing Countries.

This process of economic reordering and of reallocation of the means of production will not be free from difficulties, which will be felt particularly in a first stage, certainly marked by increased unemployment, the disappearence of less competitive enterprises and increased competition, namely from extra-Community firms.

This last aspect is particularly serious, above all if 'liberalizations without reciprocity' are allowed, which would constitute a permanent threat to Community enterprises, even those with the best performance.

At a State level, the process of economic reordering will be greatly marked by the fight against regional asymmetries, with the accompanying transfers of Community funds within its area and a more equitative distribution of incomes, always with a view to economic stabilization and development.

World economy at the present time shows recessive trends that may even be towards economic depression, unless there is proper concerted effort among the industrial countries and between them and the developing countries.

The solution to the problems of deficits and foreign indebtedness of some countries is an essential matter for lasting economic development, and the EEC economy will naturally be highly dependent on what occurs in this respect.

The future of the various economic sectors of the EEC, including that of the financial services of which insurance forms part, thus depends on a growing number of uncertainties that obviously harbour menaces, but also opportunities.

The PADOA-SCHIOPPA and CECCHINI Reports contain data of great interest for a coordinated development of Community Europe, particularly the latter, which in relation 
to the costs of the 'non-Europe' deals with the benefits that the three main financial services - banking, insurance and operators in securities - will be able to gain from the Internal Market, and points to a value of 22000 million Ecus.

The conclusions of this report, however, are not always complete and some statements that it makes need to be verified and confirmed.

The situation, therefore, is still one of expectancy, particularly as regards the future of the insurance sector in the Community, or at least in some of its member States.

Concerning strategies to be followed in the insurance system, with an eye above all to the post-1993 period, it is hard for the moment to take up definitive positions due to the complexity of the problem and the uncertainties and conditioning factors that are involved.

Apart from anything else, strategies will have to vary according to the means available, the circumstances and the comportment of competitors.

It will also be necessary, according to circumstances, to opt for defensive or offensive strategies. The latter, which are the more effective, call for the necessary means and in most cases these are considerable.

In another perspective, insurance strategies must take into account four different categories of intervening entities: clients, shareholders, intermediaries and personnel of the companies.

Bound up with the first category is the important question of the quality of the service rendered, and the protection of that same quality; with the second are connected the company's results and consolidation; with the third category, the crucial point of distribution of the products and with the fourth, the delicate problem of management, functioning and technical level of the company; in short its degree of competitiveness.

These four vectors of the problem sometimes involve contradictory strategies (for example, obtaining profits or increasing the market share, reducing prices or increasing dividends, improving service or increasing the performance), and this is another difficulty of the alternatives that must ensure a 'comparative advantage' in the environment of keen competition that already exists in the EEC, with everything pointing to a considerable increase in that competition.

\section{Some key-points}

Mention must be made of some generic themes applicable to the insurance sector and also to other financial services.

\subsection{Economic interdependence}

The growing interdependence between the economies of countries in different zones and with different levels is nowadays an incontrovertible fact.

The rates of growth of the NICs (newly industrialised countries) and of those recently called RICs (rapidly industrialised countries) are often higher than those of the economically most powerful countries.

Moreover, the evolution of the age-group composition is starting to play an increasingly important part in the movement of capital.

This means that the residents of richer countries that have a population of a more advanced average age tend to have their investments in countries that are also rich but with 
younger population, in order to ensure the income required for financing their retirement, a fact that also helps to explain the flow of European capital to the United States.

In this context, the economy of the 12 EEC countries and thcir 340 million inhabitants - which in fact represent no more than about $6.5 \%$ of the world's population - is increasingly interconnected with that of other countries.

For this reason the frcedom in the EEC and the restructuring of companies in it arc merely intermediate phascs on the way to a worldwide scale of business.

\subsection{Liberalization}

Liberalization means competition, reduction of prices and profit margin. In order to cope with this situation, companies of great financial capacity, with dominant market positions, are particularly well placed.

They will dictate the profit margins, even allowing for the anti-trust measures and decisions for disciplining free competition by the Community authorities.

Within the framework of the EEC, indcpendently of whether it is a question of 'freedom of establishment' or of 'freedom of services', the prospects for competition will continue to be far more between small and big enterprises than between small and big markets.

\subsection{Competition between governments}

Prior coordination having been relegated to a second level of preoccupation in favour of the recognition of regulations, it is essentially the market rules and forces that will bring about closer ties between the regimes of the Community countries.

Since each member State will lose most of its capacity for controlling monetary policy, harmonisation - particularly in the fiscal section - will depend on a competition in which for the first time the main actors are Governments themselves, which will have to keep watch on the 'major balance' of national accounts. This is a new situation, to be followed with interest.

\subsection{Age of alliances}

Both expansion and internationalization, apart from being interconnected in the European Community, are determining factors in the development of companies. Their costs, however, may be very high.

For this reason, strategies of alliances may be preferred to strategies of pure investment.

We have in fact entered the age of alliances, in the form of joint ventures, marketing consortia and targetcd research and production arrangements.

These are solutions which, for many companies in EEC countrics, are new and require reflection, even bcforc bcing able to count as 'European companies', whose status is still being studicd by the authorities in Brussels, since the alternative solution (EEIG) has too many limitations to be functional.

This is, in fact, a ficld that has not passed unnoticed by the main entreprencurs in insurance.

\subsection{Flexibility}

In a world that is constantly changing and dominated by a greater degree of uncertainty, flexibility is an essential factor. Evcryone is in agreement, but it is not always known how to achieve this, especially in countries where therc are conditioning factors of a legal, economic and even, sometimes, political kind. 
For each case it is necessary to seek the most feasible solution.

\subsection{Entrepreneurial identity}

For companies that are used to operating in an international environment, the 1993 Internal Market will not be a revolution and even, for the most eompctitive, will be an invitation to greater development.

Insurance companies in many cases have that experience of operating internationally, which amplifies the notion of solidarity that is a basic notion of this sector.

For those that do not have that experience, or intend to enlarge it, it is indispensable to begin with a clear and profound knowledge of their own identity, their specific compctences and capacities of realization - of their own or by resorting to outside support.

It is essential for them to know well their strength, before measuring it with that of their competitors.

This is one of the crucial data in establishing the framework of strategies for the 1993 Internal Market.

\section{Importance of regional free trade areas}

To be aware of the importance of regional trade agreements and the role they can play in the international trade in services, let's have a brief glance at EEC Internal Market, and some strategic options, that insurance companies may take in the near future.

The 1993 Internal Market is expected to achieve a more balanced situation between the insurance markets of the EEC Member States and to give European insurance a stronger position in the international scene.

At an entrepreneurial level it is interesting to follow the concentration movement between insurance companies. According to the reports produced by the Brussels Commission about competition in the EEC, 347 mergers and acquisitions occurred in the 1984-1990 period.

Of those, $144(41 \%)$ were at a national level, $113(33 \%)$ at an EEC level and $90(26 \%)$ involved both EEC and non-EEC companies.

The majority of these financial operations refers to the acquisition of controlling participations in other companies, which means that the aim of those operations was to consolidate a dominant position of some market leaders.

Because the significant number of operations at a Community level appearcd one or two years later than those at a national level, this seems to point to a corporate strategy of reinforcing positions in the home market before expanding abroad.

In 1990, the number of operations between EEC companies has increased, while the other kind of operations stabilised (35 at the national level and 22 between EEC and non-EEC companies).

Anyway, there is no doubt that EEC insurance companies are preparing themselves for a fiercer competition after 1993 and so they want to consolidate their market share before that time.

Meanwhile the market leaders are reinforcing their already dominant position. The concentration trend is slowing down but will continue in the next few years. 
When the third generation directives both on Life, non-Life business and Pension Funds are in force, the total framework of the Internal Market will be in operation, and freedom of services will be a reality between the EEC countries.

This is an important step forward, since there is no other economic space in the world with a higher degree of free trade in insurance, far behind the United States as a federal country.

In this sense the EEC can very well be regarded as an example to other countries or to other regional Free Trade Areas.

We should keep in mind that the EEC insurance Single Market was achieved in two stages: first, freedom of establishment and second, freedom of services.

This strategic choice can very well serve as a model for further GATT negotiations, since they concern a much larger and far more differentiated group of countries.

If the Uruguay Round, at least as regards insurance business, were to result in practice in a real implementation of an acceptable freedom of establishment, this could already be considered as a very important achievement.

Coming back to the EEC model, it must be considered that two important facts dominate the present international cooperation in European insurance, apart from the EEC Switzerland agreement. Those facts are the EEC-EFTA approach and EEC-Central and Eastern European Countries approach.

The negotiations between the EEC and EFTA have produced a treaty to form the European Economic Space - EES.

The implementation of EES will give a stronger bargaining power to the 18 countries which are expected to integrate this new bloc.

A different situation characterizes the contacts between the EEC and the East and Central European Countries. Before they can join EEC they have to complete the transition to market economy, which calls for some time and a lot of reforms.

Anyway some forms of association with the EEC and GATT may be found, even as a way of encouraging those reforms.

Even if this may not represent a real contribution to the GATT activity as such, it is always a positive sign for future arrangements in the area of services free trade. In fact those countries must modernise their economic structures and new technologies and financial services are among the instruments for speeding up that modernisation.

\section{Brief conclusion}

A brief conclusion could be the following:

- Insurance is, by nature, an international business;

- in an era of growing uncertainties, the development of national insurance markets, supported by adequate co-insurance and reinsurance schemes, is essential for ensuring the coverage of certain risks which tend to become greater and more sophisticated;

- the implementation of a wide geographical area where insurance trade would be gradually liberalised is a much better contribution to the developing countries than a lively competition of larger and stronger regional blocs; 
- the bargaining power of the different contracting parts in a wide multilateral negotiation is much more balanced than in a negotiation where regional blocs are the main or even the only actors ;

- the EEC's successful arrangements of the Insurance Internal Market can very well be used as a model for a very large negotiation like the ones at GATT, taking the freedom of establishment as a starting point;

- because of the danger of serious distortions that trade-offs or sectoral negotiations may cause, it is indispensable that the GATT present and future negotiations on services should be multisectorial and based on a real "reciprocity minded" agreement;

- even keeping in mind that insurance and banking are two very specific and well-defined sectors, is no longer possible to ignore the fact that cooperation instead of confrontation is the attitude that is better suited to the present international trend;

- lastly, it is also very important to remember that liberalisation of insurance trade implies an effective supervision, to be redefined and, at the same time, a cooperation between national supervision entities. 